\title{
Virus memory induces airway hyperreactivity through eosinophil activation
}

\author{
Christopher Skappak ${ }^{1 *}$, Ramses Ilarraza', Yingqi Wu' ${ }^{1}$ Erik Saude ${ }^{1}$ Darryl Adamko ${ }^{1,2}$ \\ From AllerGen NCE Inc.'s Fifth Annual Research Conference: Innovation from Cell to Society \\ Québec City, QC, Canada. 7-9 February 2010
}

\section{Objective/purpose}

Asthma is the most common chronic respiratory disease in children. Asthma exacerbation occurs when the airways acutely become obstructed, usually the result of airway inflammation. The Inflammation is caused by a unique mix of cells, and includes eosinophils. The majority of asthma exacerbations occur after a viral infection such as a common cold. Why asthmatic children develop such severe reactions to viruses is unclear. Our previous work suggests asthmatic patients develop severe airway obstruction because they have too many eosinophils in their airways before virus infection. The virus triggers these eosinophils to release harmful mediators and cause airway damage. We believe that in humans, it may be the mere presence of virus antigen that stimulates memory cells to activate the eosinophils. We hypothesize that memory $\mathrm{T}$ cell proliferation and eosinophil activation will occur in response to any airway virus for which immune memory exists, and that removal of the eosinophils will prevent airway hyperreactivity (AHR). In addition, we believe that this model is representative of virus-induced asthma exacerbation. As part of our project to develop non-invasive diagnostics using the metabolomic profile of urine through Nuclear Magnetic Resonance (NMR) spectroscopy, we are saving the urine samples from these animals. We hypothesize that there will be relevant differences between the urine profiles of each animal group, which will be applicable to humans.

\section{Methods}

Our study used two groups of guinea pigs (GPs), sensitized and non-sensitized to ovalbumin (i.p.). Both groups were infected (i.n.) with parainfluenza virus (PIV) and allowed to recover. A month after their first

${ }^{1}$ Department of Pediatrics, University of Alberta, Edmonton, Alberta, Canada Full list of author information is available at the end of the article virus exposure, and they were challenged with ovalbumin (aerosol) to simulate an allergen exposure. 2 weeks later, OVA-exposed GPs were inoculated with either the same PIV, sham or a UV-inactivated PIV. All GPs were studied 5 days following exposure to virus for airway responsiveness, inflammation, virus titers and lymphocyte memory to the virus. Urine was collected by open bladder puncture for NMR analysis from all GPs.

\section{Findings}

GPs with primary exposure to live PIV demonstrated splenic lymphocyte proliferation in-vitro, thus confirming immune memory to PIV. Both sensitized and nonsensitized GPs develop AHR and inflammation following primary and secondary PIV. The sensitized animals are more eosinophilic. Only the sensitized animals develop increased AHR in response to a secondary UV-inactivated PIV. These results support our previous in-vitro work that suggested the virus antigen is presented to memory $\mathrm{T}$ cells, which then stimulate the eosinophils. This data also suggests that the development of AHR is related to the timing of virus exposure and the degree of eosinophil stimulation, not the degree of virus infection. Urine metabolomic profiles are being analyzed.

\section{Deliverables}

Guinea Pigs develop a memory response to PIV and upon re-exposure to PIV viral antigens this immune memory appears to cause increased AHR and inflammation in only the sensitized animals. These novel data will lead to a publication.

\section{Relevance}

This study will identify the cellular pathway that is involved in a virus induced asthma exacerbation. Knowing this pathway will allow researchers to develop targeted methods that may prevent virus induced asthma 
exacerbations. Metabolomic characterization of virus induced asthma exacerbations in a Guinea Pig model will enable us to identify relevant markers to be studied in the human version of the disease.

\section{Author details}

${ }^{1}$ Department of Pediatrics, University of Alberta, Edmonton, Alberta, Canada.

${ }^{2}$ Medicine, University of Alberta, Edmonton, Alberta, Canada.

Published: 26 November 2010

doi:10.1186/1710-1492-6-S3-P26

Cite this article as: Skappak et al:: Virus memory induces airway

hyperreactivity through eosinophil activation. Allergy, Asthma \& Clinical

Immunology 2010 6(Suppl 3):P26.

Submit your next manuscript to BioMed Central and take full advantage of:

- Convenient online submission

- Thorough peer review

- No space constraints or color figure charges

- Immediate publication on acceptance

- Inclusion in PubMed, CAS, Scopus and Google Scholar

- Research which is freely available for redistribution

Submit your manuscript at www.biomedcentral.com/submit 